\title{
DISKRETISASI MODEL LORENZ DENGAN ANALOGI PERSAMAAN BEDA
}

\author{
Siti Shifatul Azizah \\ Politeknik Kota Malang \\ e-mail: shifa_1902@yahoo.ac.id
}

\begin{abstract}
ABSTRAK
Diskretisasi model merupakan prosedur transformasi model kontinu ke model diskret. Diskretisasi dilakukan dengan metode analogi persamaan beda, yaitu dengan menganalogikan persamaan diferensial yang menggunakan aturan limit, dengan persamaan beda yang menggunakan beda $h$ antar titik waktu diskret. Model yang digunakan dalam penelitian ini adalah model Lorenz yang merepresentasikan aliran konveksi udara di atmosfer yang terjadi karena perbedaan suhu. Tujuan dari penelitian ini adalah mengkonstruksi model diskret Lorenz dan membandingkan perilaku antar model diskret dan model kontinu. Langkah yang dilakukan terdiri dari tiga tahap, yaitu konstruksi $t$ diskret, diskretisasi masing-masing persamaan dan validasi model diskret dengan membandingkan hasil simulasi grafik kontinu dan diskret. Hasil dari penelitian ini didapatkan model diskret Lorenz dalam bentuk umum: $X_{m+1}=(1-\sigma h) X_{m}+\sigma h Y_{m}, Y_{m+1}=\left(r-Z_{m}\right) h X_{m}+(1-h) Y_{m}, Z_{m+1}=(1-b h) Z_{m}+h X_{m} Y_{m}$ dengan $m \in N$ dan $h \rightarrow 0$. Perbandingan perilaku setiap variabel pada model kontinu dan diskret diamati saat $h=$ $\{0.1 ; 0.01 ; 0.001,0.0001\}$ dengan parameter $\sigma=10, b=\frac{8}{3} \operatorname{dan} r=28$ dan nilai awal $\left(X_{0}, Y_{0}, Z_{0}\right)=(1,1,1)$. Untuk $h$ semakin kecil perbedaan antara model kontinu dan diskret akan semakin sedikit pula. Dari hasil simulasi diskret, efek chaos terjadi pada $t \geq 15$ menit. Saat $h \leq 10^{-3}$, model diskret yang dibentuk dapat mengimplementasikan perilaku variabel kontinu dan gejala kekacauan (chaos) di sekitar titik kesetimbangan.
\end{abstract}

Kata Kunci: Diskretisasi, Model Lorenz, Persamaan Beda, Model Kontinu, Model Diskret, Chaos

\section{ABSTRACT}

Discretization of model is transformation a model in continuous form to be a discrete one. It can be done by using difference equation analogy method. It analogues a differential equation that use limit rules with difference equation that use difference $h$ between the points of discrete time. The model in this research is Lorenz model. This model represents a convection motion in atmosphere that occurs due to temperature difference.The purpose of research is show construction the discrete version of Lorenz model and know comparison of discrete Lorenz behavior and continuous one. This research was done by three steps. First, construct time $t$ for discrete case. Second, discretization each of equations in Lorenz system, and third, validation the discrete model that is obtained, by simulating its graphics and compare it with continuous one. The results of this research obtain a discrete Lorenz model in general form: $X_{m+1}=(1-\sigma h) X_{m}+\sigma h Y_{m}, Y_{m+1}=\left(r-Z_{m}\right) h X_{m}+(1-h) Y_{m}, Z_{m+1}=(1-b h) Z_{m}+h X_{m} Y_{m}$ with $m \in N$ and $h \rightarrow 0$. Comparison of the behavior of each variables on a continuous and discrete model is observed when $h=\{0.1 ; 0.01 ; 0.001,0.0001\}$ with the parameter $\sigma=10, b=\frac{8}{3}$ and $r=28$ and initial value $\left(X_{0}, Y_{0}, Z_{0}\right)=$ $(1,1,1)$. For smaller $h$, the difference between continuous and discrete model will be less too. From, simulation of discrete graphics, chaotic behavior can be shown from $t \geq 15$ minutes. When $h \leq 0.001$, discrete model can implement the behavior of continuous variables and chaotic behavior around equilibrium point.

Keywords: Discretization, Lorenz Model, Difference Equation, Continuous Model, Discrete Model, Chaos

\section{PENDAHULUAN}

Menurut Liu dan Hussain (2012), diskretisasi merupakan proses kuantisasi sifatsifat kontinu. Kuantisasi diartikan sebagai proses pengelompokan sifat-sifat kontinu pada selangselang tertentu (step size). Kegunaan diskretisasi adalah untuk mereduksi dan menyederhanakan data, sehingga didapatkan data diskret yang lebih mudah dipahami, digunakan dan dijelaskan. Oleh karena itu, hasil pembelajaran dengan bentuk diskret dipandang Dougherty (1995) sebagai hasil yang cepat dan akurat dibandingkan hasil dari bentuk kontinu. Diskretisasi dapat dilakukan dengan berbagai metode, salah satunya yaitu metode analogi persamaan beda. 
Menurut Kamus Bahasa Indonesia (2008), analogi merupakan persesuaian atau penyetaraan dari dua hal yang berlainan. Adapun konsep analogi persamaan beda muncul dari pengertian persamaan kontinu dan diskret. Meyer (1985) menjelaskan bahwa persamaan kontinu merupakan persamaan yang mencakup perubahan sesaat dan secara matematis dinyatakan dengan persamaan diferensial (differential equation). Sedangkan persamaan diskret menggambarkan perubahan yang tidak sesaat dan dinyatakan dalam persamaan beda (difference equation). Dari pengertian-pengertian ini, diketahui bahwa analogi persamaan beda merupakan penyesuaian persamaan diferensial dengan persamaan beda.

Persamaan beda adalah persamaan yang menghubungkan nilai fungsi $y$ yang diketahui, dan satu atau lebih beda $\Delta y, \Delta^{2} y, \ldots, \Delta^{n} y$, dengan $\Delta y(x)=y(x+h)-y(x)$, untuk setiap nilai $x$ anggota himpunan bilangan yang memuat selesaian dari fungsi (Goldberg, 1958).

Tirtana (2008) menunjukkan bahwa analogi persamaan beda di samping memiliki kesederhanaan algoritma, juga terbukti memiliki kemampuan yang baik dalam menghasilkan model diskret yang merepresentasikan model kontinunya. Dalam penelitiannya, dilakukan diskretisasi model AIDS dengan persamaan beda sehingga menghasilkan model diskret AIDS yang dapat menjelaskan pola perkembangan variabel pada model kontinunya dengan sangat baik, Untuk menunjukkan bahwa metode tersebut aplikatif untuk model lain, maka penelitian ini mengembangkannya pada model lain, yaitu model Lorenz.

Secara matematis, model Lorenz didefinisikan sebagai struktur tiga dimensi berbentuk persamaan diferensial biasa nonlinear (Robinson, 2004):

$$
\left.\begin{array}{l}
\dot{X}=-\sigma X+\sigma Y \\
\dot{Y}=r X-Y-X Z \\
\dot{Z}=-b Z+X Y
\end{array}\right\}
$$

Dalam bidang meteorologi, model Lorenz digunakan untuk memodelkan aliran konveksi yaitu pergerakan udara (angin) di atmosfer yang mengalami pergolakan karena perbedaan temperatur, dengan $X$ adalah intensitas gerakan konveksi, $Y$ besar perbedaan temperatur horizontal antara arus naik dan turun, dan $Z$ besar perbedaan suhu vertikal (Dalmedico, 2001). Parameter $\sigma$ adalah bilangan Prandtl, merupakan hasil bagi dari viskositas dan konduktivitas termal, parameter $r$ menunjukkan perbedaan suhu pada lapisan yang dipanaskan, dan parameter $b$ bergantung pada keadaan geometri dari lapisan fluida (0. Knill, 2012). Warmer Turker, membuktikan bahwa pada saat nilai parameter $\sigma=10, b=\frac{8}{3}$ dan $r=28$ maka sistem Lorenz memiliki ketergantungan sensitif terhadap kondisi awal dan memiliki gejala chaos (Robinson, 2004). Berdasarkan temuan ini, maka penelitian ini menggunakan nilai parameter tersebut dalam mengamati gejala chaos pada model Lorenz kontinu dan diskret.

Tujuan dari penelitian ini adalah mengkonstruksi model diskret Lorenz dan membandingkan perilaku dinamik model Lorenz kontinu dengan model Lorenz diskret. Untuk itu, dilakukan proses pendiskretisasian model, simulasi grafik model kontinu dan model diskret, dan analisis perbandingan perilaku dan gejala chaos setiap variabel yang ditunjukkan oleh kedua jenis grafik.

\section{KAJIAN TEORI}

\section{Persamaan Diferensial}

Persamaan diferensial adalah persamaan yang mengandung turunan dari satu atau lebih peubah tak bebas dengan satu atau lebih peubah bebas (Ross, 1984: 3). Turunan sebuah fungsi $f$ adalah fungsi lain $f^{\prime}$ (dibaca "f aksen") yang nilainya pada sebarang bilangan $c$ didefinisikan sebagai:

$$
f^{\prime}(c)=\lim _{h \rightarrow 0} \frac{f(c+h)-f(c)}{h}
$$

asal limit ini ada (Purcell dan Vanberg, 2003)

Suatu sistem yang memuat $n$ buah persamaan diferensial, dengan $n$ buah fungsi yang tidak diketahui, di mana $n \geq 2$ disebut sistem persamaan diferensial (Finizio dan Ladas, 1982). Bentuk umum dari sistem $n$ persamaan orde pertama adalah sebagai berikut:

$$
\left.\begin{array}{c}
\frac{d x_{1}}{d t}=g_{1}\left(t, x_{1}, x_{2}, \ldots, x_{n}\right) \\
\frac{d x_{2}}{d t}=g_{2}\left(t, x_{1}, x_{2}, \ldots, x_{n}\right) \\
\vdots \\
\frac{d x_{n}}{d t}=g_{n}\left(t, x_{1}, x_{2}, \ldots, x_{n}\right)
\end{array}\right\}
$$

dengan $\frac{d x_{n}}{d t}$ turunan fungsi $x_{n}$ terhadap $t, g_{n}$ adalah fungsi yang bergantung pada variabel $x_{1}, x_{2}, \ldots ., x_{n}$ dan $t$.

Jika suatu sistem persamaan diferensial berbentuk:

$$
\left.\begin{array}{l}
\frac{d x}{d t}=F(x, y, z) \\
\frac{d y}{d t}=G(x, y, z) \\
\frac{d z}{d t}=H(x, y, z)
\end{array}\right\}
$$

dengan fungsi $F, G, H$ secara eksplisit tidak dipengaruhi oleh variabel waktu $t$, maka (2.3) disebut sistem autonomus (Boyce, 1986). 


\section{Titik Kesetimbangan}

Titik kritis sistem (2.3) adalah titik $\bar{x}=(x, y, z)$ sehingga $F(\bar{x})=G(\bar{x})=H(\bar{x})=0$.

Titik kritis $\bar{x}$ merupakan solusi-solusi sistem (2.9) yang bernilai konstan, sebab pada $\bar{x}$, $\frac{d x}{d t}=0, \frac{d y}{d t}=0$ dan $\frac{d z}{d t}=0$. Keadaan yang menyebabkan $\frac{d x}{d t}=0, \frac{d y}{d t}=0$ dan $\quad \frac{d z}{d t}=0$

disebut keadan setimbang, sehingga titik kritis tersebut disebut juga titik kesetimbangan (Edward dan Penney, 2001 dalam Sazali, 2001).

\section{Kestabilan}

Menurut Hariyanto (1992) sifat dan jenis kestabilan hampir seluruhnya bergantung pada akar-akar karakteristik. Kestabilan titik kesetimbangan suatu sistem dinamik diberikan pada Teorema 1 berikut:

\section{Teorema 1:}

a. Titik kesetimbangan dari sistem (2.3) bersifat stabil asimtotik, jika nilai eigen $\lambda_{1}$ dan $\lambda_{2}$ pada persamaan karakteristiknya adalah real dan negatif atau mempunyai bagian real negatif.

b. Titik kesetimbangan dari sistem (2.3) bersifat stabil tetapi tidak stabil asimtotik, jika nilai eigen $\lambda_{1}$ dan $\lambda_{2}$ pada persamaan karakteristiknya adalah imaginer murni.

c. Titik kesetimbangan dari sistem (2.3) bersifat tak stabil, jika nilai eigen $\lambda_{1}$ dan $\lambda_{2}$ pada persamaan karakteristiknya adalah real dan juga positif atau mempunyai bagian yang positif.

\section{Persamaan Beda}

Persamaan beda adalah persamaan yang menghubungkan nilai fungsi $y$ yang diketahui, dan satu atau lebih beda $\Delta y, \Delta^{2} y, \ldots, \Delta^{n} y$, untuk setiap nilai $x$ anggota suatu himpunan bilangan (Goldberg, 1958). Meyer (1985) menuliskan bentuk umum dari persamaan beda adalah sebagai berikut:

atau ditulis:

$$
x(k+1)-x(k)=y(x(k), k)
$$

$x_{k+1}-x_{k}=y$
$k=0,1,2, \ldots n, n \in N$.

\section{Analogi antara Kalkulus Beda dan Kalkulus Diferensial}

Fakta bahwa turunan sebuah fungsi didefinisikan sebagai limit dari hasil bagi beda menghasilkan banyak analogi menarik antara kalkulus beda hingga dan kalkulus diferensial. Untuk sebuah fungsi $y$ yang diberikan, maka fungsi baru Dy yang memiliki nilai di $x$ dinyatakan sebagai:

$$
D y(x)=\lim _{h \rightarrow 0} \frac{y(x+h)-y(x)}{h}=\lim _{h \rightarrow 0} \frac{\Delta y(x)}{h}
$$

Jika limitnya ada maka fungsi baru di atas disebut turunan. $D$ adalah operator diferensiasi yang menghasilkan turunan fungsi. $\frac{\Delta y(x)}{h}$ adalah kemiringan dari garis lurus yang menghubungkan titik-titik pada kurva $y$ di $x$ dengan $y$ di $(x+h)$. Dengan menggunakan notasi ini, kalkulus diferensial dapat diinyatakan dengan beberapa analogi formula kalkulus beda berikut (Goldberg, 1958).

Tabel 1. Analogi Kalkulus Diferensial dengan Persamaan Beda

\begin{tabular}{cc}
\hline Kalkulus Beda & Kalkulus Diferensial \\
\hline$\Delta \boldsymbol{y}(\boldsymbol{x})$ & $D y(x)$ \\
$=\boldsymbol{y}(\boldsymbol{x}+\boldsymbol{h})-\boldsymbol{y}(\boldsymbol{x})$ & $=\lim _{h \rightarrow 0} \frac{y(x+h)-y(x)}{h}$ \\
& $=\lim _{h \rightarrow 0} \frac{\Delta y(x)}{h}$ \\
\hline$\Delta^{\boldsymbol{n}} \boldsymbol{y}(\boldsymbol{x})=\Delta\left(\Delta^{\boldsymbol{n - 1}} \boldsymbol{y}\right)$, & $D^{n} y=D\left(D^{n-1} y\right)$ \\
$\boldsymbol{n}=\mathbf{1}, \mathbf{2}, \ldots$ & $n=1,2, \ldots$ \\
\hline$\Delta(\boldsymbol{c y})=\boldsymbol{c} \Delta \boldsymbol{y}$ & $D(c y)=c D y$ \\
\hline
\end{tabular}

Sumber: (Goldberg, 1958)

\section{Pendekatan Persamaan Diferensial dengan Persamaan Beda}

Berdasarkan hubungan antara operator beda " $\Delta$ " dengan operator diferensial $D$ yang telah disinggung pada bagian sebelumnya, didapatkan beberapa hubungan antara persamaan beda dan persamaan diferensial. Pada bagian ini akan ditunjukkan kemungkinan mendapatkan solusi persamaan diferensial sebagai solusi limit yang tepat dengan persamaan beda. Ambil sebuah fungsi $y$ yang terdefinisi di setiap $x \in R$ pada interval $a \leq x \leq b$, yang memenuhi persamaan diferensial berikut

$$
D y(x)=\frac{d y(x)}{d x}=A y(x)+B, a \leq x \leq b
$$

dengan $A$ dan $B$ adalah sebarang konstan dengan $A \neq 0$. Diasumsikan nilai $y$ di $x=a$ ditentukan sebagai nilai awal $y(a)=y_{0}$ (Goldberg, 1958).

Untuk mendekati persamaan diferensial dengan persamaan beda, pertama dilakukan penggantian interval kontinu $a \leq x \leq b$ dengan himpunan diskret dari nilai $x$ yang memungkinkan persamaan beda terdefinisi pada himpunan tersebut. Ambil $n$ bilangan bulat positif yang membagi interval $a$ sampai $b$ dalam $n$ bagian yang sama, dengan panjang masingmasing interval:

$$
h=\frac{b-a}{n}
$$

pembagian interval ini menghasilkan titik-titik diskret pada selang $[a, b]$ berikut: 
$x_{0}=a, x_{1}=a+h, x_{2}=a+2 h, \ldots, x_{n}=a+n h=b$

Sehingga setiap titik diskret $x_{n}, \forall n=0,1,2, \ldots$ akan berkorespondensi dengan:

$$
y_{n}=y\left(x_{n}\right)=y\left(x_{0}+n h\right)
$$

ingat bahwa:

$$
\begin{aligned}
\operatorname{Dy}\left(x_{k}\right) & =A y\left(x_{k}\right)+B \\
\lim _{h \rightarrow 0} \frac{\Delta y_{k}}{h} & =A y\left(x_{k}\right)+B
\end{aligned}
$$

dengan menggunakan persamaan beda, maka persamaan (2.9) dapat dinyatakan dengan:

$$
\begin{aligned}
\frac{\Delta y_{k}}{h} & =A y\left(x_{k}\right)+B \\
\frac{y_{k+1}-y_{k}}{h} & =A y_{k}+B \\
y_{k+1} & =y_{k}+h\left(A y_{k}+B\right) \\
y_{k+1} & =(1+h A) y_{k}+B h, k=0,1,2, \ldots, n-1
\end{aligned}
$$

$y_{k+1}$ dapat ditentukan nilainya setelah diterapkan nilai awal fungsi $y_{0}$ (Goldberg, 1958).

\section{Model Lorenz}

Persamaan Lorenz dikembangkan dari sistem persamaan yang digunakan oleh Saltzman untuk mempelajari proses termodinamika yang dikenal dengan istilah konveksi. Konveksi menciptakan gaya yang bertanggungjawab untuk gerakan atmosfer bumi. Jika diberikan suatu fluida, konveksi akan terjadi ketika fluida dipanaskan dari bawah dan didinginkan dari atas. Perbedaan suhu fluida antara bagian atas dan bawah atmosfer dijangkau fluida dalam gulungan-gulungan silinder (Danforth, 2001).

Sel konveksi digunakan untuk mensimulasikan perilaku atmosfer secara kualitatif. Matahari yang memanaskan atmosfer dan permukaan bumi, menyediakan sumber energi panas yang besar. Laut dan ruang angkasa mengalirkan energi tersebut keluar atmosfer. Udara hangat dari permukaan bumi naik ke angkasa, sampai menjangkau titik-titik embun yang akan berkondensasi membentuk awan. Pada lapisan terluar atmosfer udara didinginkan oleh ruang angkasa, sehingga menjadi lebih padat dan jatuh ke bagian bawah. Dengan cara ini, konveksi yang merupakan aliran udara dingin dan hangat terjadi di atmosfer dan menimbulkan pengaruh pada cuaca (Danforth, 2001). Sel konveksi ditunjukkan dalam Gambar 1 berikut.

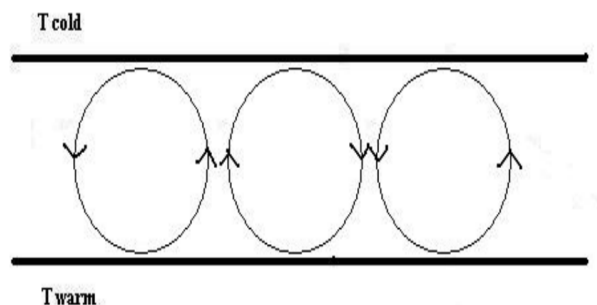

Gambar 1. Sel Konveksi

(Sumber:Danforth, 2001)
Persoalan konveksi ini sebenarnya melibatkan dua fenomena yaitu fenomena gerak dan fenomena difusi termal. Pada dasarnya untuk membahas keseluruhan fenomena ini adalah dengan mencari solusi dari persamaan NavierStokes (gerak) dan persamaan difusi termal. Kedua persamaan tersebut diekspansi oleh Lorenz sehingga dapat digunakan dalam kasus nonlinier. Solusi yang dipelajari Lorenz dibentuk dalam model berikut (Sulaiman, 2000):

$$
\begin{aligned}
\dot{X} & =-\sigma X+\sigma Y \\
\dot{Y} & =r X-Y-X Z \\
\dot{Z} & =-b Z+X Y
\end{aligned}
$$

Titik menyatakan turunan terhadap non dimensi waktu $\tau=\pi^{2} H^{-2}\left(1+a^{2}\right) k t$, dengan $\sigma=k^{-1} v$ adalah bilangan Prandtl, $r=R_{c}^{-1} R_{0}$ dan $b=4\left(1+a^{2}\right)^{-1}$. Persamaan (2.10) adalah persamaan konveksi yang dikenal dengan sistem persamaan Lorenz atau model Lorenz (Sulaiman, 2000).

Paramater model Lorenz terdiri dari $\sigma, b, r$. Parameter $\sigma$ adalah bilangan Prandtl yang merupakan hasil bagi viskositas dan konduktivitas termal, suatu nilai atau harga untuk menentukan distribusi temperatur pada suatu aliran. Parameter $b$ merupakan nilai yang menunjukkan ekspansi termal. Dan parameter $r$ sebagai bilangan Rayleigh yang didefinisikan sebagai rasio dari bilangan Rayleigh kritis dan bilangan Rayleigh awal. Bilangan Rayleigh mengindikasikan keberadaan dan kekuatan konveksi pada suatu fluida.

Sifat model Lorenz adalah nonlinier yang ditunjukkan oleh suku $X Y$ dan $X Z$, simetri yang berarti bahwa persamaan invariant terhadap $(X, Y) \rightarrow(-X,-Y)$, oleh karena itu, jika $(X(t), Y(t), Z(t))$ adalah solusi persamaan, maka $(-X(t),-Y(t), Z(t))$ juga merupakan solusi dari persamaan tersebut (Anonim, 2012).

\section{Kekacauan (chaos)}

Chaos adalah suatu perilaku evolusi jangka panjang yang menunjukkan kekacauan dan memenuhi kriteria matematika tertentu serta terjadi pada sistem nonlinear deterministik (Williams, 1997). Chaos bersifat aperiodik dan memiliki ketergantungan pada kondisi awal (Ipek, 2009).

Sifat chaos aperiodik, yakni suatu kondisi yang tidak beraturan dan dalam grafik tidak ditemukan perulangan ke bentuk awal grafik. Tampilan grafik yang acak tersebut adalah bentuk dari respon sistem terhadap kondisi awal yang diberikan. Perbedaan pemberian nilai awal, akan menyebakan perbedaan hasil yang sangat besar pada sistem chaos.

Jika $X(t)$ adalah titik kesetimbangan model, dan diberikan gangguan dengan nilai yang sangat dekat dengan titik tersebut, sehingga 
dapat dikatakan $X(t)+\delta(t)$, di mana $\delta \rightarrow 0$, misal $\delta=10^{-15}$ maka chaos akan menghasilkan efek kekacauan yang sangat tidak terduga. Pemberian gangguan ini dapat diilustrasikan oleh Gambar 2 berikut (Anonim, 2012).

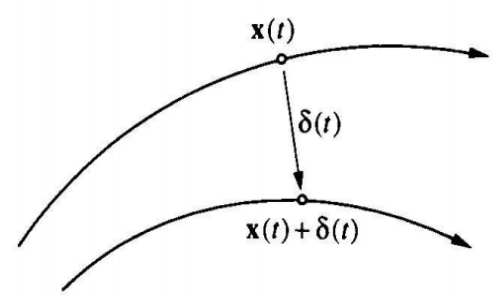

Gambar 2. Gangguan $\delta$ di Sekitar Titik $X(t)$

Kondisi pada Gambar 2 dapat diterapkan pada sebuah model dalam rangka mengetahui kesensitivan terhadap kondisi awal.

\section{PEMBAHASAN}

\section{Konstruksi Bentuk Diskret Model Lorenz} berikut:

Model Lorenz kontinu adalah sebagai

$$
\left.\begin{array}{l}
f_{1}: \dot{X}=-\sigma X+\sigma Y \\
f_{2}: \dot{Y}=r X-Y-X Z \\
f_{3}: \dot{Z}=-b Z+X Y
\end{array}\right\}
$$

Konstruksi bentuk diskret (diskretisasi) dari model Lorenz yang berbentuk sistem persamaan tiga dimensi dilakukan dengan mentransformasi satu per satu persamaannya. Proses diskretisasi diawali dengan penggantian interval kontinu $t_{0} \leq t \leq t_{m}$ dengan himpunan $t$ diskret yang memungkinkan persamaan beda terdefinisi pada himpunan tersebut.

\section{Konstruksi $\boldsymbol{t}$ Diskret}

Pada kasus diskret, variabel pada model Lorenz berubah seiring dengan perubahan waktu $t$ yang bergerak dengan beda sebesar $\Delta t=h$. Perubahan nilai variabel untuk $t$ diskret diilustrasikan oleh Gambar 3.
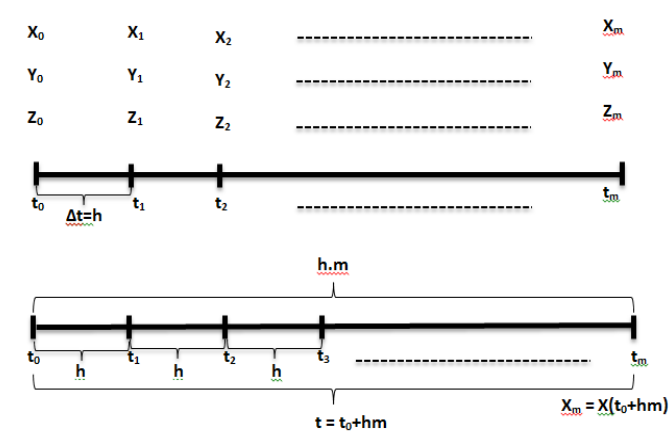

Gambar 3. Skema Perubahan $t$ Diskret

Skema di atas menjelaskan bahwa interval kontinu $t_{0} \leq t \leq t_{m}$ diubah ke dalam bentuk $t$ diskret yang berupa himpunan $t=\left\{t_{0}, t_{1}, \ldots, t_{m}\right\}$.
Dengan mengambil $m$ bilangan asli yang membagi interval $t_{0} \leq t \leq t_{m}$ dalam $m$ bagian yang sama, diperoleh interval antar titik diskret berikut:

$$
h=\frac{t_{m}-t_{0}}{m}, m=1,2,3, \ldots, k ; k \in N
$$

secara rekursif, titik-titik diskret dalam interval $\left[t_{0}, t_{m}\right]$ dapat ditentukan sebagai berikut:

$$
\begin{aligned}
t_{1} & =t_{0}+\Delta t_{0}=t_{0}+h \\
t_{2} & =t_{0}+2 \Delta t_{0}=t_{0}+2 h \\
t_{3} & =t_{0}+3 \Delta t_{0}=t_{0}+3 h \\
& \vdots \\
t_{m} & =t_{0}+m \Delta t_{0}=t_{0}+m h \\
t_{m+1} & =t_{0}+(m+1) \Delta t_{0}=t_{0}+(m+1) h
\end{aligned}
$$

sehingga fungsi $X_{1}, X_{2}, \ldots, X_{m} ; Y_{1}, Y_{2}, \ldots, Y_{m}$ dan $Z_{1}, Z_{2}, \ldots, Z_{m}$ dapat dinyatakan sebagai berikut:

$$
\begin{aligned}
X_{1} & =X\left(t_{0}+h\right) \\
X_{2} & =X\left(t_{0}+2 h\right) \\
X_{3} & =X\left(t_{0}+3 h\right) \\
& \vdots \\
X_{m} & =X\left(t_{0}+m h\right) \\
X_{m+1} & =X\left(t_{0}+(m+1) h\right)
\end{aligned}
$$

Dengan cara yang sama, dapat ditentukan pula bahwa $Y_{m}=Y\left(t_{0}+m h\right)$ dan $Z_{m}=Z\left(t_{0}+m h\right)$. Jika diasumsikan $t=t_{m}=t_{0}+m h$ maka $X_{m}, Y_{m}$ dan $Z_{m}$ dapat ditulis menjadi:

$$
\begin{aligned}
X_{m} & =X(t) \\
Y_{m} & =Y(t) \\
Z_{m} & =Z(t)
\end{aligned}
$$

Saat $t_{m+1}=t_{0}+(m+1) h$, maka dapat diperolehkondisi berikut:

$$
\begin{aligned}
t_{m+1} & =t_{0}+(m+1) h \\
& =t_{0}+m h+h \\
& =\left(t_{0}+m h\right)+h \\
& =t+h
\end{aligned}
$$

Sehingga didapatkan $X_{m+1}, Y_{m+1}$ dan $Z_{m+1}$ berikut:

$$
\begin{aligned}
X_{m+1} & =X(t+h) \\
Y_{m+1} & =Y(t+h) \\
Z_{m+1} & =Z(t+h)
\end{aligned}
$$

Persamaan (3.3) dan (3.5) selanjutnya akan digunakan dalam diskretisasi masing-masing persamaan $f_{1}, f_{2}, f_{3}$.

\section{Diskretisasi $f_{1}$}

Diberikan $f_{1}$ :

$$
\dot{X}=-\sigma X+\sigma Y
$$


tanda titik pada $X$ menyatakan turunan pertama fungsi $X$ terhadap waktu $t$. Berdasarkan definisi turunan, maka (3.6) dapat dinyatakan sebagai berikut,

$$
\begin{aligned}
\frac{d X}{d t} & =-\sigma X+\sigma Y \\
\lim _{\Delta t \rightarrow 0} \frac{X(t+\Delta t)-X(t)}{\Delta t} & =-\sigma X(t)+\sigma Y(t)
\end{aligned}
$$

dengan menggunakan persamaan beda, maka persamaan (3.7) dapat dinyatakan sebagai:

$$
\frac{X(t+\Delta t)-X(t)}{\Delta t}=-\sigma X(t)+\sigma Y(t)
$$

karena $\Delta t=h$ maka ruas kiri persamaan (3.8) dapat ditulis kembali sebagai,

$$
\begin{aligned}
& X(t+h)-X(t)=h(-\sigma X(t)+\sigma Y(t)) \\
& X(t+h)-X(t)=-\sigma h X(t)+\sigma h Y(t)
\end{aligned}
$$

Selanjutnya, persamaan (3.9) ditransformasi ke dalam fungsi diskret dengan $t$ diskret yang diberikan pada persamaan (3.3) dan (3.5). Sehingga, persamaan (3.9) menjadi,

$$
\begin{aligned}
X_{m+1}-X_{m} & =-\sigma h X_{m}+\sigma h Y_{m} \\
X_{m+1} & =X_{m}-\sigma h X_{m}+\sigma h Y_{m} \\
X_{m+1} & =(1-\sigma h) X_{m}+\sigma h Y_{m}
\end{aligned}
$$

\section{Diskretisasi $\boldsymbol{f}_{2}$}

Diberikan $f_{2}$ sebagai berikut,

$$
\dot{Y}=r X-Y-X Z
$$

tanda titik pada $Y$ menyatakan turunan pertama fungsi $Y$ terhadap waktu $t$. Berdasarkan definisi turunan, maka (3.11) dapat dituliskan sebagai berikut,

$$
\begin{gathered}
\frac{d Y}{d t}=r X-Y-X Z \\
\lim _{\Delta t \rightarrow 0} \frac{Y(t+\Delta t)-Y(t)}{\Delta t}=r X(t)-Y(t)-X(t) Z(t)
\end{gathered}
$$

dengan menggunakan persamaan beda, dan dengan $\Delta t=h$ maka persamaan (3.12) dapat dinyatakan sebagai

$$
\begin{aligned}
\frac{Y(t+\Delta t)-Y(t)}{\Delta t} & =r X(t)-Y(t)-X(t) Z(t) \\
\frac{Y(t+h)-Y(t)}{h} & =r X(t)-Y(t)-X(t) Z(t) \\
Y(t+h)-Y(t) & =h(r X(t)-Y(t)-X(t) Z(t)) \\
Y(t+h)-Y(t) & =h r X(t)-h Y(t)-h X(t) Z(t)
\end{aligned}
$$

Selanjutnya, persamaan (3.13) ditransformasi ke dalam fungsi diskret dengan $t$ diskret yang diberikan pada persamaan (3.3) dan (3.5). Sehingga, persamaan (3.13) menjadi,

$$
\begin{aligned}
Y_{m+1}-Y_{m} & =h r X_{m}-h Y_{m}-h X_{m} Z_{m} \\
Y_{m+1} & =h r X_{m}+Y_{m}-h Y_{m}-h X_{m} Z_{m} \\
Y_{m+1} & =h r X_{m}-h X_{m} Z_{m}+Y_{m}-h Y_{m} \\
Y_{m+1} & =\left(r-Z_{m}\right) h X_{m}+(1-h) Y_{m}
\end{aligned}
$$

Diskretisasi $\boldsymbol{f}_{\mathbf{3}}$

Diberikan $f_{3}$ sebagai berikut,

$$
\dot{Z}=-b Z+X Y
$$

dengan menguraikan ruas kiri sesuai dengan definisi turunan $Z$ terhadap $t$, dan dengan memberikan $\Delta t=h$, maka (3.15) menjadi,

$$
\begin{aligned}
\frac{d Z}{d t} & =-b Z+X Y \\
\lim _{\Delta t \rightarrow 0} \frac{Z(t+\Delta t)-Z(t)}{\Delta t} & =-b Z(t)+X(t) Y(t)
\end{aligned}
$$

dengan menggunakan persamaan beda, persamaan (3.16) dapat ditulis

$$
\frac{Z(t+\Delta t)-Z(t)}{\Delta t}=-b Z(t)+X(t) Y(t)
$$

dengan mensubstitusi $\Delta t=h$, maka persamaan (3.17) menjadi

$$
\begin{aligned}
& \frac{Z(t+h)-Z(t)}{h}=-b Z(t)+X(t) Y(t) \\
& Z(t+h)-Z(t)=h(-b Z(t)+X(t) Y(t)) \\
& Z(t+h)-Z(t)=-b h Z(t)+h X(t) Y(t))
\end{aligned}
$$

Selanjutnya persamaan (3.18) dianalogikan dengan menggunakan persamaan (3.3) dan (3.5), sehingga menjadi,

$$
\begin{aligned}
Z_{m+1}-Z_{m} & =-b h Z_{m}+h X_{m} Y_{m} \\
Z_{m+1} & =Z_{m}-b h Z_{m}+h X_{m} Y_{m} \\
Z_{m+1} & =(1-b h) Z_{m}+h X_{m} Y_{m}
\end{aligned}
$$

Dari uraian di atas, maka diperoleh bentuk diskret dari persamaan $f_{1}, f_{2}$ dan $f_{3}$ yang dapat disusun dalam sistem persamaan Lorenz diskret berikut,

$$
\begin{aligned}
& X_{m+1}=(1-\sigma h) X_{m}+\sigma h Y_{m} \\
& Y_{m+1}=\left(r-Z_{m}\right) h X_{m}+(1-h) Y_{m} \\
& Z_{m+1}=(1-b h) Z_{m}+h X_{m} Y_{m}
\end{aligned}
$$

di mana $m=1,2,3, \ldots, k$ dengan $k \in N$, dan $h \rightarrow 0$.

\section{Analisis Perbandingan Perilaku Variabel pada Model Kontinu dan Diskret Lorenz}

Setelah dilakukan diskretisasi model, langkah selanjutnya adalah validasi model diskret dengan membandingkan grafik model diskret yang telah dikonstruksi dengan model kontinunya. Sebuah grafik kontinu dengan selang waktu tertentu akan didekati oleh grafik diskret 
yang membagi selang tersebut dengan titik-titik diskret berinterval tetap $(h)$.

Besar interval $h$ mendekati nol, dalam penelitian ini diberikan:

$$
h=\{0.1 ; 0.01 ; 0.001,0.0001\}
$$

dengan tiga selang waktu kontinu yang berbeda, yaitu $0 \leq t \leq 1$ menit, $0 \leq t \leq 10$ menit dan $0 \leq t \leq 30$ menit. Dengan nilai parameter $\sigma=10, b=\frac{8}{3}, r=28$, dan nilai awal $X_{0}=1$, $Y_{0}=1$, dan $Z_{0}=1$. Model Lorenz kontinu pada persamaan (3.1) dan model Lorenz diskret pada persamaan (3.20), dapat ditunjukkan oleh Gambar 4.

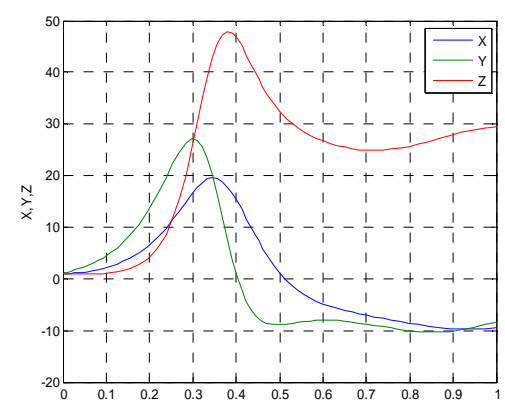

Gambar 4. Grafik Kontinu Model Lorenz dalam $0 \leq t \leq 1$ Menit

Intensitas dari gerak konveksi $(X)$ ditunjukkan dalam $X(t)$ gerakan, besar perbedaan temperatur horizontal $(Y)$ dan perbedaan temperatur vertikal (Z) diukur dalam derajat Fahrenheit (F), sedangkan waktu $t$ dalam satuan menit.

Pada saat kontinu, perkembangan variabel akan terlihat sebagaimana Gambar 4 Terdapat beberapa pola perilaku dari setiap variabel yang ditunjukkan. Perkembangan $X$ menunjukkan bahwa dalam selang $0 \leq t \leq 1$ menit, kuantitas gerak konveksi akan mengalami kenaikan sampai dengan mendekati 20 gerakan pada saat 0,35 menit pertama. Perkembangan ini sebanding dengan $Y$ yang menunjukkan perbedaan suhu horizontal, dalam 0,30 menit pertama selalu mengalami kenaikan sampai mendekati $25^{\circ} \mathrm{F}$. Sedangkan perbedaan suhu secara vertikal meningkat lebih besar pada saat mendekati 0,38 menit pertama, yaitu sampai dengan mendekati $50^{\circ} \mathrm{F}$. Perilaku $X, Y, Z$ sebanding satu sama lain, kenaikan satu variabel akan diikuti oleh kenaikan variabel lainnya.

Perilaku ini akan dibandingkan dengan dengan perilaku variabel pada model diskret. Grafik model diskret ditunjukkan oleh Gambar 5.

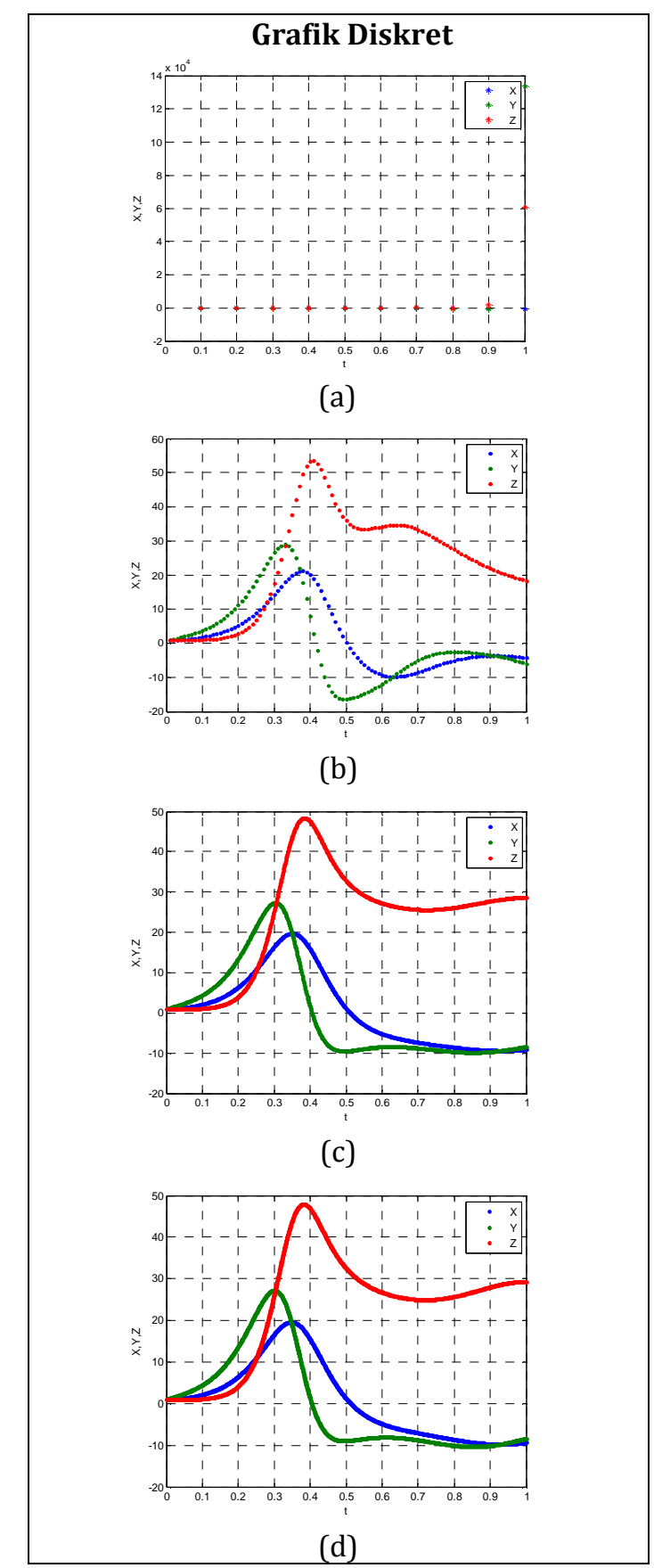

Gambar 5. Grafik Diskret Model Lorenz dalam $0 \leq t \leq 1$ Menit dalam $h$ yang bervariasi: (a) $h=0.1$, (b) $h=0.01$, (c) $h=0.001$, dan (d) $h=0.0001$

Gambar 5 menunjukkan bahwa untuk $h=0.1$ model diskret dalam selang $0 \leq t \leq 1$ menit belum mewakili pola perkembangan model kontinu yang ditunjukkan oleh Gambar 3. Nilai $X, Y, Z$ yang terlampau besar saat $h=0.1$ mengakibatkan 10 titik waktu tidak dapat mendekati interval nilai fungsi kontinu yaitu $-20 \leq X, Y, Z \leq 50$. Semakin kecil $h$, yaitu diambil $h=0.01$ menunjukkan grafik diskret mendekati lintasan grafik kontinu. Dengan mengambil lebih kecil $h$, yaitu $h=0.001$, titik $t$ diskret akan semakin banyak dan rapat, sehingga 
sebagaimana terlihat pada Gambar 5(c), model kontinu telah dapat diwakili oleh model diskret, dengan pola perilaku variabel yang hampir sama. Selanjutnya, kembali di ambil $h=0.0001$. Ditunjukkan bahwa grafik diskret tetap mempertahankan bentuknya, yaitu menunjukkan kesamaan dalam menggambarkan pola perkembangan model kontinu. Sehingga untuk selang $0 \leq \leq 1$ menit, dapat dinyatakan bahwa model diskret menunjukkan pola perilaku yang sama dengan model kontinu saat $h \leq 0.001$.

Selanjutnya, untuk menunjukkan bahwa model diskret mampu mewakili pola perilaku model kontinu saat $h \leq 0.001$ berlaku untuk interval lain, maka akan dilakukan uji dengan interval yang lebih panjang, yaitu $0 \leq t \leq$ 1 menit. Grafik kontinu untuk interval $0 \leq t \leq 1$ menit, ditunjukkan oleh Gambar 6 .

Pola perkembangan setiap variabel dalam interval $0 \leq t \leq 1$ menit adalah mulai menunjukkan fluktuasi. Grafik berosilasi dengan setimbang di sekitar titik $(X, Y, Z)=(-8,-8,27)$. Analisis titik kesetimbangan ini akan dibahas lebih detail pada sub bab selanjutnya.

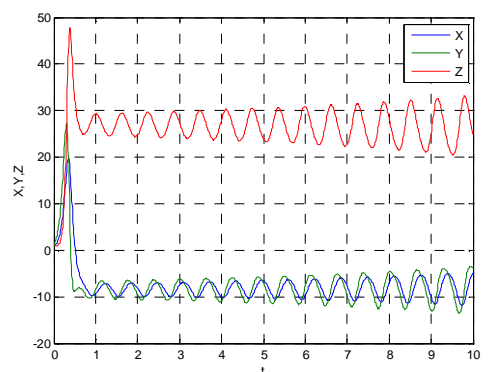

Gambar 6. Grafik Kontinu Model Lorenz dalam $0 \leq t \leq 10$ Menit

Pola perilaku variabel pada grafik kontinu di atas akan dibandingkan dengan pola perilaku grafik diskret pada Gambar 7.

Dalam selang $0 \leq t \leq 10$ menit, grafik diskret dengan $h=0.1$ kembali menunjukkan adanya keterbatasan kemampuan dalam merepresentasikan grafik kontinu. Interval $h$ yang sedemikian besar, menyebabkan fungsi bernilai besar dan tidak terdefinisi pada selang fungsi $-20 \leq X, Y, Z \leq 50$. Dengan $h=0.01$, grafik diskret mulai memperlihatkan osilasinya, walaupun lintasan masing-masing plot variabel diskret masih menyebar dan bergeser dari lintasan kontinu. Pola perkembangan setiap variabel diskret sangat mendekati keadaan kontinu, yaitu berfluktuasi secara terus menerus dan menunjukkan adanya kestabilan pada saat $h=0.001$. Demikian pula saat $h=0.0001$, kembali ditunjukkan bahwa keadaan diskret tidak mengalami perubahan yang besar dari keadaan diskret saat $h=0.001$. Sehingga secara umum, untuk selang $0 \leq t \leq 10$ menit, model kontinu Lorenz dapat diwakili oleh model diskret dengan $h \leq 0.001$.

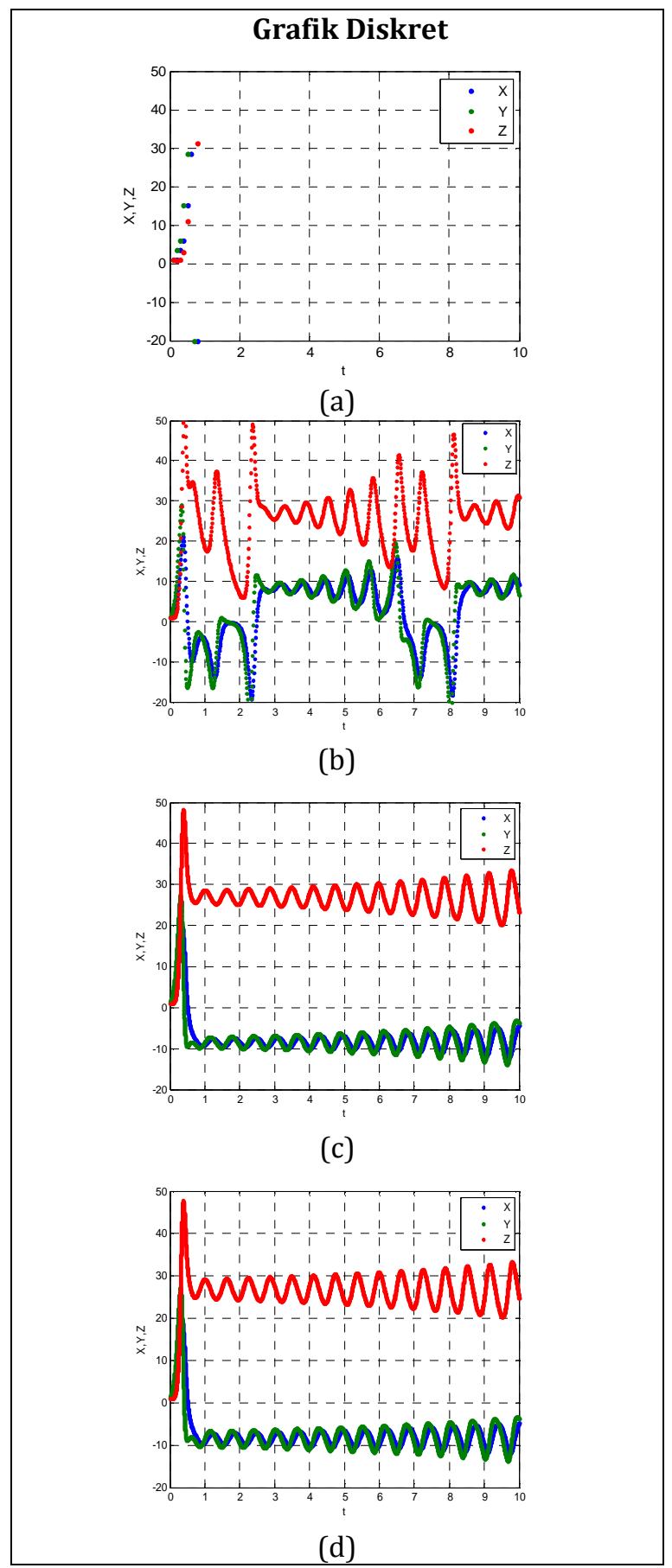

Gambar 7. Grafik Diskret Model Lorenz dalam $0 \leq t \leq 10$ Menit dalam $h$ yang bervariasi: (a) $h=0.1$, (b) $h=0.01$, (c) $h=0.001$, dan (d) $h=0.0001$

Selanjutnya, untuk memperumum kesimpulan bahwa grafik diskret model Lorenz dapat mengimplementasikan perilaku kontinunya saat $h \leq 0.001$, maka kembali dilakukan uji untuk selang waktu pengamatan yang lebih besar, yaitu $0 \leq t \leq 30$ menit. Grafik kontinu untuk selang waktu tersebut diberikan pada Gambar 8. 


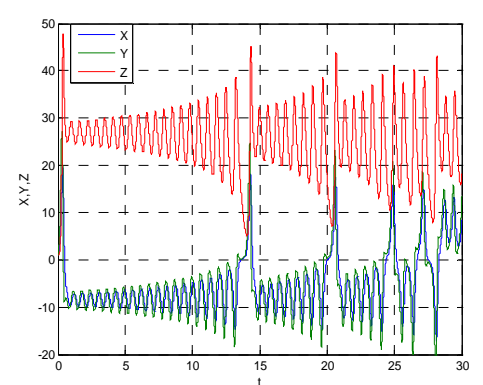

Gambar 8. Grafik Kontinu Model Lorenz dalam $0 \leq t \leq 30$ Menit

Keadaan kontinu pada interval $0 \leq t \leq 30$ menit menunjukkan adanya gejala chaos yang ditandai dengan keacakan osilasi grafiknya. Pola perilaku setiap variabel pada saat kontinu, berfluktuasi secara aperiodik dalam lintasan yang sama dengan lintasannya. Perkembangan $X$ dan $Y$ bergerak dalam interval $-20 \leq X, Y \leq 25$, sedangkan $Z$ berfluktuasi dalam interval $0 \leq Z \leq 50$.

Keadaan diskret untuk interval $0 \leq t \leq 30$ menit dapat dilihat pada Gambar 9 berikut.

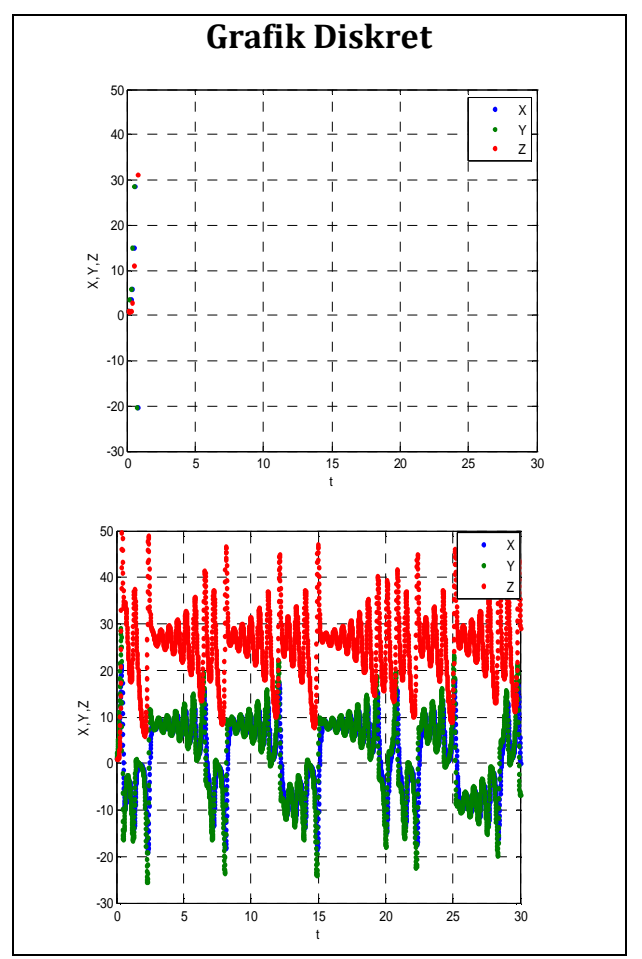

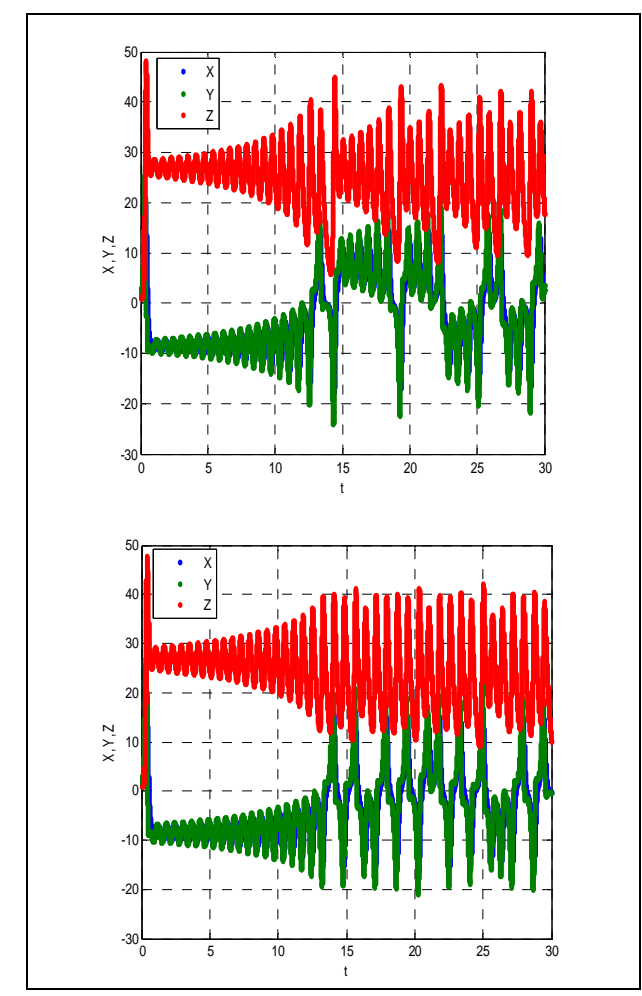

Gambar 9. Grafik Diskret Model Lorenz dalam $0 \leq t \leq 30$ Menit dalam $h$ yang bervariasi, berturut-turut dari atas adalah grafik diskret dengan $h=0.1, \quad h=0.01, h=0.001$, dan $h=0.0001$

Model diskret dengan $0 \leq t \leq 30$ menit dan $h=0.1$ menunjukkan perilaku variabel yang cenderung tidak berbeda dengan perilaku saat diuji dengan dua selang sebelumnya yaitu menunjukkan galat yang besar karena nilainya yang terlampau besar dalam mendekati model kontinu. Untuk $h=0.01$ ditunjukkan bahwa perkembangan variabel masih terlalu lebar dari lintasan. Hal ini dikarenakan jumlah titik-titik yang membagi selang tersebut belum cukup mewakili perkembangan semua titik di saat kontinu. Selanjutnya saat $h=0.001$, pola perkembangan lebih mendekati pola kontinu. Namun saat $h$ diambil lebih kecil lagi yaitu $h=0.0001$, grafik yang sebelumnya pada saat $0 \leq t \leq 1$ menit dan $0 \leq t \leq 10$ menit cenderung tidak menunjukkan perubahan pola perkembangan lagi untuk $h \leq 0.001$, pada selang waktu yang lebih besar yaitu $0 \leq t \leq 30$ menit menunjukkan adanya perubahan yang signifikan mulai menit ke-15. Namun tetap mempertahankan bentuknya, dalam arti, perkembangan setiap variabel masih berada pada lintasan masing-masing, walaupun perkembangannya telah sedikit berbeda dengan kondisi kontinunya. Hal ini menunjukkan adanya efek kekacauan (chaos) yang oleh banyak teori disebutkan dimiliki oleh sistem persamaan 
Lorenz ini. Analisis kekacauan Lorenz akan diuraikan lebih detail pada bagian berikutnya.

Dari uji validitas, yang dilakukan dengan membandingkan grafik diskret dan grafik kontinu pada tiga selang waktu, yaitu $0 \leq t \leq 1$ menit, $0 \leq t \leq 10$ menit dan $0 \leq t \leq 30$ menit serta interval untuk titik diskret yang bernilai $h=0.1 ; 0.01 ; 0.001 ; 0.0001$, dapat diketahui secara umum bahwa perilaku setiap variabel menunjukkan perbedaan yang signifikan saat model diskret menggunakan $h=0.1$, dengan memperkecil nilai $h$ menjadi $h=0.01$ didapatkan model diskret yang lebih mendekati pola perkembangan kontinu yang menunjukkan adanya fluktuasi grafik dengan lintasan yang lebih lebar daripada lintasan kontinu. Semakin kecil $h$ maka diperoleh perilaku diskret yang semakin mendekati perilaku kontinu, yaitu saat $h=0.001$. Apabila $h$ kembali diperkecil, perilaku grafik diskret memunculkan dua kemungkinan, pertama yaitu mempertahankan keadaannya sebagaimana ditunjukkan pada saat $h=0.001$, dan kedua mengalami sedikit perubahan dalam lintasannya. Kemungkinan kedua ini, terjadi untuk selang pengamatan pada menit-menit yang cukup besar, yaitu $t \geq 15$ menit. Namun secara umum, keadaan kontinu telah dapat dicapai saat model diskret dikonstruksi dengan $h \leq 0.001$.

Dari kedua grafik, baik kontinu maupun diskret dengan $h \leq 0.001$ menunjukkan bahwa kuantitas gerak konveksi berkembang sebanding dengan perkembangan perbedaan suhu horisontal, keduanya berkembang dalam kisaran nilai yang tidak jauh berbeda. Sedangkan untuk perbedaan suhu vertikal, meskipun memiliki pola perkembangan dengan fluktuasi yang sebanding, tetapi nilainya jauh lebih tinggi dari dua variabel lainnya.

\section{Analisis Perbandingan Perilaku Kekacauan (chaos) pada Model Kontinu dan Diskret Lorenz}

Perilaku chaos pada model kontinu dan diskret dapat diamati di sekitar titik kesetimbangannya. Untuk menunjukkan kekacauan yang menyebabkan sistem mengalami perubahan yang signifikan, maka diberikan gangguan berupa $\delta$ dengan besar $\delta \rightarrow 0$ di sekitar titik kesetimbangan. Dalam hal ini, besar gangguan yang diberikan dipilih sangat kecil, yaitu $\delta=10^{-6}$ yang diterapkan pada salah satu variabel, yaitu $X$. Langkah untuk membandingkan gejala chaos pada model kontinu dan diskret diawali dengan analisis titik kesetimbangan model kontinu, analisis kekacauan di sekitar titik kesetimbangan model kontinu, dan analisis kekacauan di sekitar titik kesetimbangan model diskret. Dalam hal ini, dipilih model diskret dengan $h \leq 0.001$ yaitu $h=\{0.001,0.0001\}$ yang pada pembahasan sebelumnya telah ditunjukkan dapat mendekati model kontinu dengan baik, dan dari tiga interval waktu yang diberikan, dipilih interval waktu $0 \leq t \leq 30$ menit karena pada pembahasan sebelumnya dinyatakan bahwa kekacauan grafik terlihat pada $t \geq 15$ menit. Berikut akan ditunjukkan analisis titik kesetimbangan model Lorenz sebelum mendapat gangguan.

Titik kesetimbangan sistem persamaan Lorenz (3.1) diperoleh saat sistem berada dalam keadaan setimbang, yang terjadi saat $\frac{d X}{d t}=0$, $\frac{d Y}{d t}=0$ dan $\frac{d Z}{d t}=0$. Sehingga didapatkan sistem berikut

$$
\left.\begin{array}{l}
f_{1}: 0=-\sigma X+\sigma Y \\
f_{2}: 0=r X-Y-X Z \\
f_{3}: 0=-b Z+X Y
\end{array}\right\}
$$

Dari $f_{1}$ diketahui bahwa $X=Y$, yang menyebabkan $f_{2}$ menjadi

$$
\begin{aligned}
& 0=r X-X-X Z \\
& 0=X(r-1-Z)
\end{aligned}
$$

Persamaan (3.22) menyebabkan $X=0$ atau $Z=r-1$. Pilih $X=0$ sehingga $Y=0$. Nilai ini mengakibatkan $Z$ pada $f_{3}$ juga bernilai $Z=0$. Dengan demikian titik kesetimbangan pertama dari sistem (3.1) adalah

$$
\left(X^{*}, Y^{*}, Z^{*}\right)=(0,0,0)
$$

Selanjutnya akan ditentukan titik kesetimbangan kedua. Ingat bahwa dari $f_{1}$, didapatkan $X=Y$ dan dari $f_{2}$ didapatkan $Z=r-1$, yang mengakibatkan $f_{3}$ menjadi

$$
\begin{aligned}
& 0=-b(r-1)+X^{2} \\
& X= \pm \sqrt{b(r-1)} \\
& Y= \pm \sqrt{b(r-1)}
\end{aligned}
$$

Karena model Lorenz memiliki sifat simetri, di mana persamaan akan invariant pada $(X, Y) \rightarrow(-X,-Y)$, maka

$(\sqrt{b(r-1)}, \sqrt{b(r-1)},(\mathrm{r}-1)) \quad$ sebagai titik kesetimbangan sistem mengakibatkan $(-\sqrt{b(r-1)},-\sqrt{b(r-1)},(\mathrm{r}-1)) \quad$ juga akan menjadi titik kesetimbangan sistem. Sehingga secara umum, titik kesetimbangan yang tidak nol untuk sistem persamaan Lorenz dapat dituliskan sebagai berikut,

$$
\begin{aligned}
P^{+} & =\left(X^{*}, Y^{*}, Z^{*}\right)^{+} \\
& =(\sqrt{b(r-1)}, \sqrt{b(r-1)},(\mathrm{r}-1)) \\
P^{-} & =\left(X^{*}, Y^{*}, Z^{*}\right)^{-} \\
& =(-\sqrt{b(r-1)},-\sqrt{b(r-1)},(\mathrm{r}-1))
\end{aligned}
$$

Untuk nilai parameter yang dibatasi pada $b=\frac{8}{3}$ dan $r=28$, maka titik kesetimbangan pada persamaan (3.23) dapat diberikan sebagai berikut, 


$$
P^{ \pm}=( \pm 8,48 ; \pm 8,48 ; 27)
$$

Selanjutnya akan dianalisis kestabilan dari titik kesetimbangan yang telah diperoleh. Untuk titik tetap pertama, matriks Jacobi di sekitar $(0,0,0)$ adalah

$$
J_{1(0,0,0)}=\left[\begin{array}{ccc}
-\sigma & \sigma & 0 \\
r & -1 & 0 \\
0 & 0 & -b
\end{array}\right]
$$

Dapat ditentukan nilai eigen yang memenuhi $|J-\lambda I|=0$ dengan $I$ matriks identitas, sebagai berikut.

$$
\left|\begin{array}{ccc}
\sigma+\lambda & \sigma & 0 \\
r & 1+\lambda & 0 \\
0 & 0 & b+\lambda
\end{array}\right|=0
$$

Sehingga diperoleh persamaan karakteristik berikut

$$
(\lambda+b)\left(\lambda^{2}+(1+\sigma) \lambda+(1-r) \sigma\right)=0
$$

Dengan demikian, didapatkan nilai eigen,

$$
\begin{aligned}
& \lambda_{1}=-b \\
& \lambda_{2}=\frac{-(1+\sigma)-\sqrt{(1+\sigma)^{2}-4 \sigma(1-r)}}{2} \\
& \lambda_{3}=\frac{-(1+\sigma)+\sqrt{(1+\sigma)^{2}-4 \sigma(1-r)}}{2}
\end{aligned}
$$

Untuk nilai $b=\frac{8}{3}, \quad \sigma=10$ dan $r=28$, nilai eigennya adalah

$$
\begin{aligned}
& \lambda_{1}=-2.67 \\
& \lambda_{2}=-22,82 \\
& \lambda_{3}=11,82
\end{aligned}
$$

Karena terdapat $\lambda_{1,2}<0$ dan $\lambda_{3}>0$ maka berdasarkan Teorema 1, titik kesetimbangan pertama tidak stabil.

Selanjutnya akan dianalisis kestabilan titik kesetimbangan tak nol, yaitu

$$
P^{ \pm}=( \pm 8,48 ; \pm 8,48 ; 27) \text {. }
$$

Matriks Jacobi di sekitar titik $( \pm 8,48 ; \pm 8,48 ; 27)$ dengan nilai parameter yang telah diberikan adalah

$$
J_{P^{ \pm}( \pm 8,48 ; \pm 8,48 ; 27)}=\left[\begin{array}{ccc}
-10 & 10 & 0 \\
1 & -1 & \mp 8,48 \\
\pm 8,48 & \pm 8,48 & -2,67
\end{array}\right]
$$

Persamaan karakteristiknya adalah

$$
\lambda^{3}+13,67 \lambda^{2}-42,67 \lambda-138,67=0
$$

Sehingga nilai eigennya:

$$
\begin{aligned}
& \lambda_{1}=-13,85 \\
& \lambda_{2}=0.09+10,19 i \\
& \lambda_{3}=0.09-10,19 i
\end{aligned}
$$

Karena $\lambda_{1}<0$ dan unsur real dari $\lambda_{2,3}>0$ maka titik kesetimbangan tak nol untuk model Lorenz adalah tidak stabil.

Selanjutnya akan diamati gejala kekacauan (chaos) yang terjadi di sekitar titik kesetimbangan model kontinu Lorenz. Dengan memberikan gangguan $\delta \rightarrow 0$ pada variabel $X$, maka titik kesetimbangan baru adalah $\left(X^{*}+\delta, Y^{*}, Z^{*}\right)$. Titik kesetimbangan pertama sebelum dan sesudah mendapat gangguan dapat ditunjukkan oleh Gambar 10.

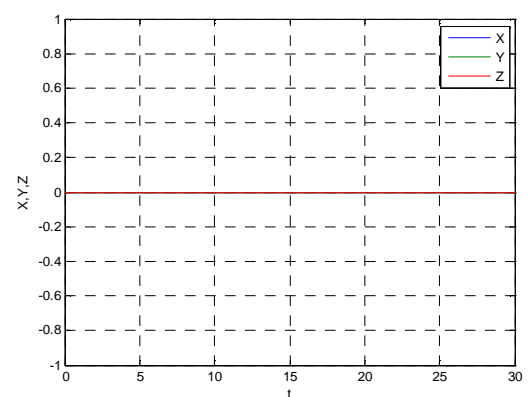

(a)

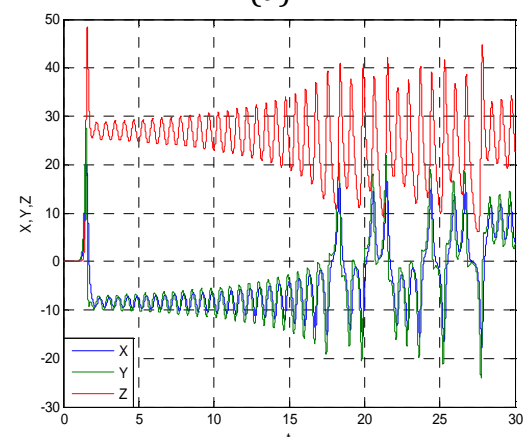

(b)

Gambar 10. (a) Grafik Model Kontinu dengan titik kesetimbangan $\left(X^{*}, Y^{*}, Z^{*}\right)=$ $(0,0,0)$ sebelum mendapat gangguan. (b) Grafik Model Kontinu dengan titik kesetimbangan $\left(X^{*}, Y^{*}, Z^{*}\right)=$ $\left(10^{-6}, 0,0\right)$ sesudah mendapat gangguan.

Berdasarkan Gambar 10(a) dan 10(b), diketahui bahwa gangguan yang sangat kecil pada variabel $X$ menyebabkan perubahan yang signifikan pada sistem Lorenz. Fakta ini menandakan bahwa sistem sensitif terhadap pemberian nilai awal, dan penerimaan input yang sederhana pada sistem telah menghasilkan keluaran yang kompleks. Gejala ini merupakan bukti bahwa sistem memiliki gejala chaos di sekitar titik kesetimbangan pertama.

Keadaan ini tidak diikuti oleh titik kesetimbantak nol. Gangguan diberikan di sekitar titik kesetimbangan tak nol, keadaan grafik sebelum dan sesudah diberikan gangguan di sekitar titik kesetimbangan tak nol, ditampilkan dalam Gambar 11. 


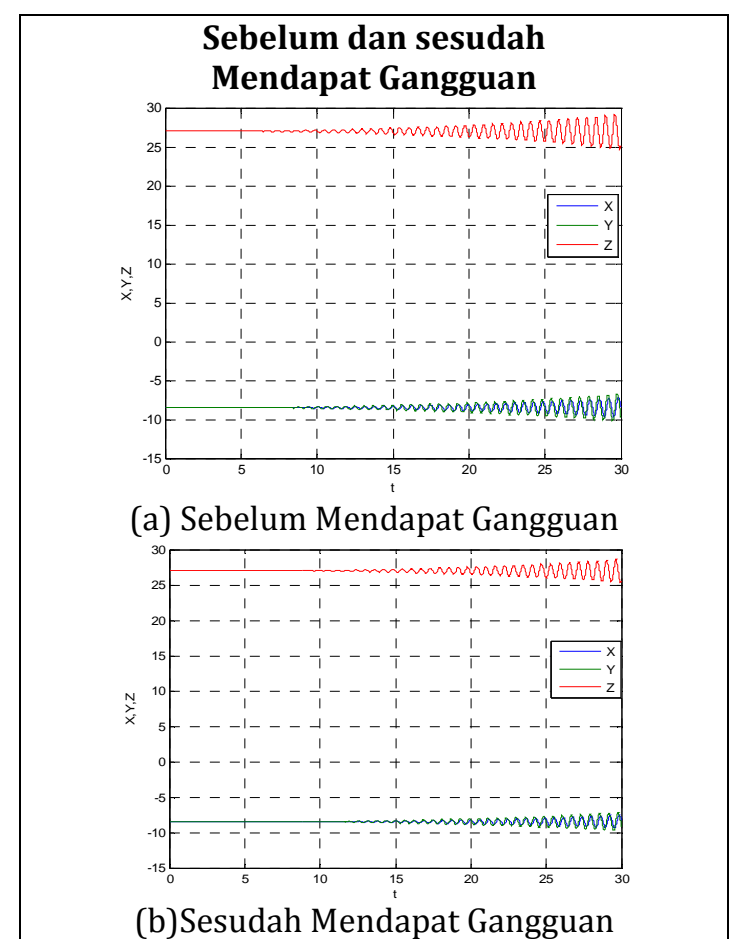

Gambar 11. Grafik Model Lorenz Kontinu sebelum dan sesudah diberikan gangguan di sekitar titik kesetimbangan. (a) Titik Kesetimbangan $P^{-}=(-8,48 ;-8,48 ; 27)$, (b) Titik Kesetimbangan $P^{-}=(-8,48+$ $\left.10^{-6} ;-8,48 ; 27\right)$

Pada saat titik kesetimbangan $P^{+}=$ $(8,48 ; 8,48 ; 27)$, pemberian gangguan di sekitar titik kesetimbangan ditunjukkan oleh Gambar 12 .

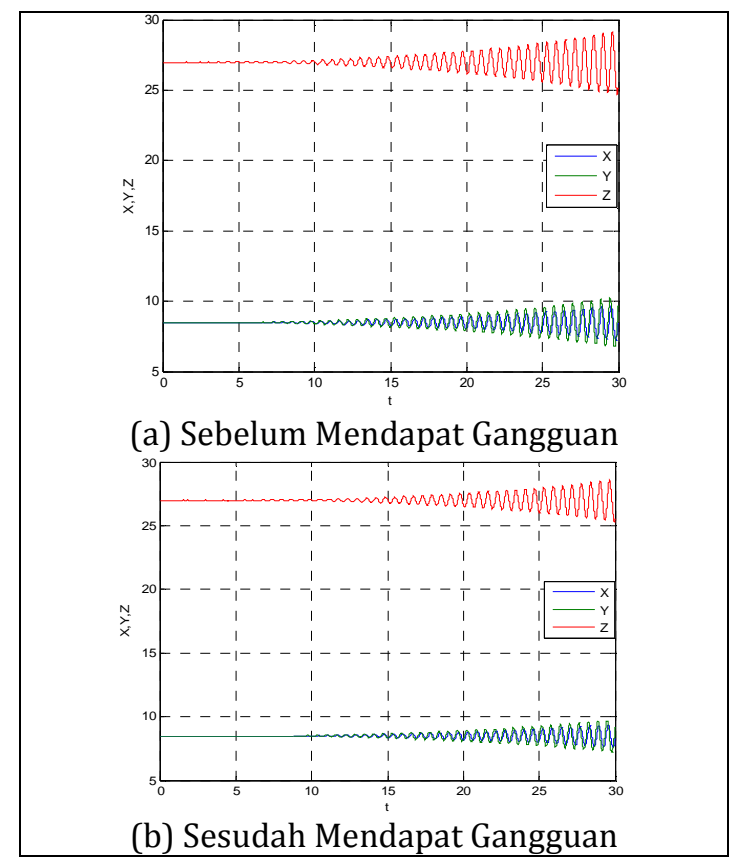

Gambar 12. Grafik Model Lorenz Kontinu sebelum dan sesudah diberikan gangguan di sekitar titik kesetimbangan.
(a) Titik Kesetimbangan $P^{+}=$

$(8,48 ; 8,48 ; 27$ (b) Titik Kesetimbangan $P^{+}=\left(8,48+10^{-6} ; 8,48 ; 27\right.$

Berikut akan ditunjukkan titik kesetimbangan model diskret dengan $h=0.001$ sebelum dan sesudah diberikan gangguan $\delta=10^{-6}$ di sekitar titik $\left(X^{*}, Y^{*}, Z^{*}\right)=(0,0,0)$ oleh Gambar 13 .

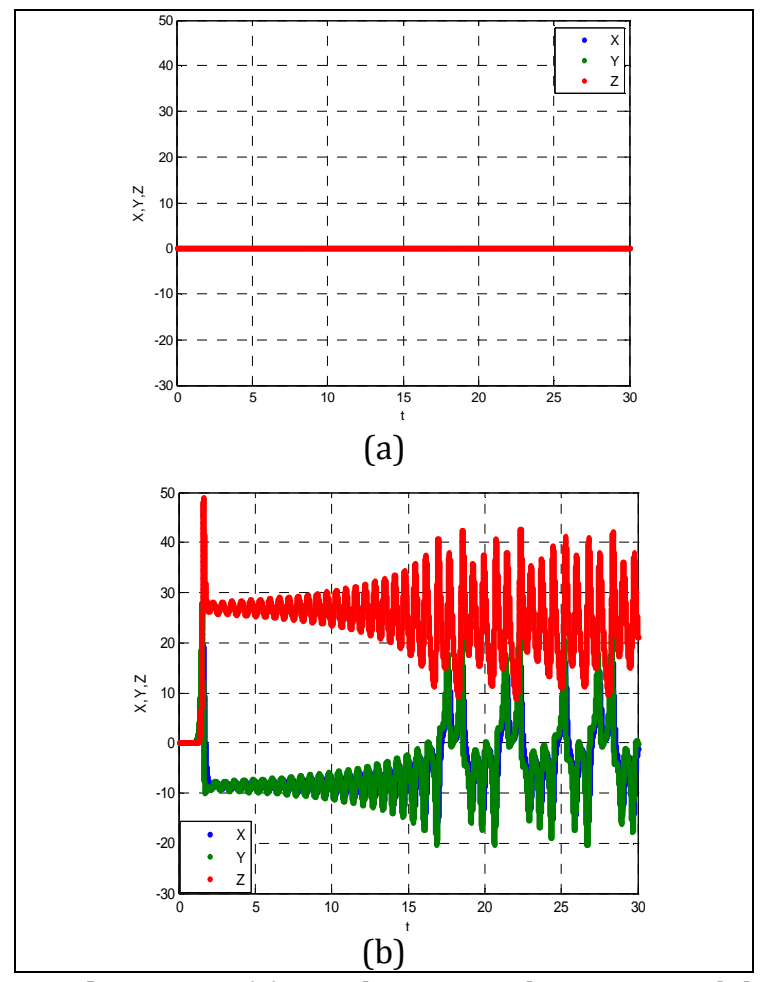

Gambar 13. (a) Titik Kesetimbangan Model Diskret dengan $h=0.001$ Lorenz di $\left(X^{*}, Y^{*}, Z^{*}\right)=(0,0,0), \quad$ (b) Titik Kesetimbangan Model Diskret Lorenz dengan $h=0.001 \mathrm{di} \quad\left(X^{*}+\delta, Y^{*}, Z^{*}\right)=$ $\left(10^{-6}, 0,0\right)$

Keadaan serupa Gambar 13 di atas juga ditunjukkan oleh model diskret dengan $h=0.0001$. Perubahan sebelum dan sesudah pemberian gangguan di sekitar titik kesetimbangan pada model diskret $h=0.0001$ diberikan pada Gambar 14.

Dari Gambar 13 (a) dan (b) dan Gambar 14 (a) dan (b), dapat ditunjukkan bahwa dalam keadaan diskret juga terjadi perubahan yang signifikan sebelum dan sesudah diberikan gangguan di sekitar titik kesetimbangan. Hal ini menunjukkan bahwa sistem diskret juga memiliki sensitivitas terhadap pemberian nilai awal. Dengan sistem diskret juga memiliki efek chaos di sekitar titik kesetimbangan $\left(X^{*}, Y^{*}, Z^{*}\right)=(0,0,0)$.

Selanjutnya gejala chaos pada kondisi diskret dibandingkan dengan chaos dalam kondisi kontinu. Untuk itu, dibandingkan Gambar 13 (b) dan 14 (b) yang mewakili gejala chaos pada kondisi diskret dan Gambar 12 (b) untuk gejala chaos pada kondisi kontinu. Kedua gambar 
ini menunjukkan bahwa osilasi grafik yang mengandung chaos baik dalam kondisi kontinu maupun diskret, menunjukkan pola yang serupa, yakni berfluktuasi dalam lintasan yang sama secara aperiodik saat $t \geq 15$ menit.

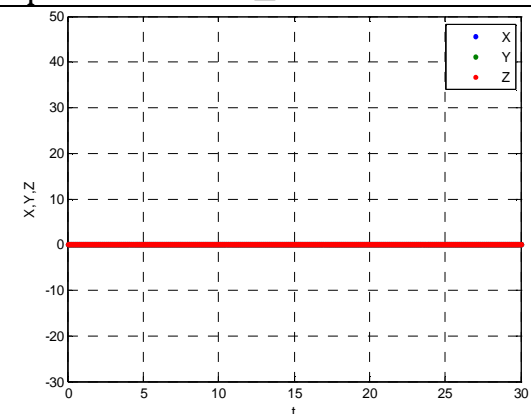

(a)

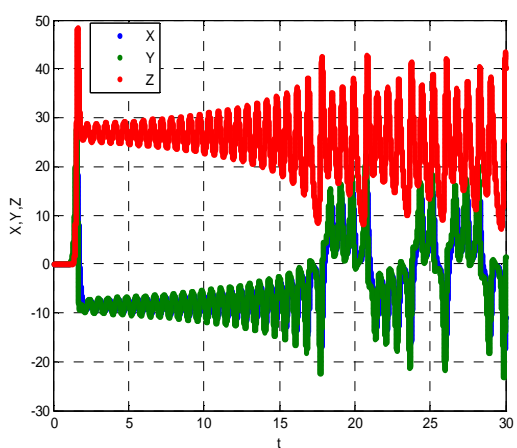

(b)

Gambar 14. (a) Titik Kesetimbangan Model Diskret dengan $h=0.0001$ Lorenz di $\left(X^{*}, Y^{*}, Z^{*}\right)=(0,0,0), \quad$ (b) Titik Kesetimbangan Model Diskret Lorenz dengan $h=0.001 \mathrm{di} \quad\left(X^{*}+\delta, Y^{*}, Z^{*}\right)=$ $\left(10^{-6}, 0,0\right)$

Berdasarkan hasil pengamatan yang dilakukan, dapat ditunjukkan bahwa model kontinu Lorenz dengan parameter $\sigma=10, b=\frac{8}{3}$ dan $r=28$ memiliki gejala chaos di sekitar titik kesetimbangan $\left(X^{*}, Y^{*}, Z^{*}\right)=(0,0,0)$. Keadaan ini dapat direpresentasikan dengan baik oleh model diskret Lorenz dengan $h \leq 0.001$.

\section{PENUTUP}

Berdasarkan hasil penelitian, dapat disimpulkan bahwa konstruksi bentuk diskret model Lorenz dengan menggunakan analogi persamaan beda dilakukan dengan tiga tahap, tahap pertama adalah konstruksi waktu $t$ untuk kasus diskret, tahap kedua adalah diskretisasi masing-masing persamaan penyusun sistem persamaan Lorenz dan tahap ketiga adalah validasi dengan simulasi perbandingan grafik. Bentuk diskret model Lorenz yang dihasilkan adalah

$$
\begin{aligned}
X_{m+1} & =(1-\sigma h) X_{m}+\sigma h Y_{m} \\
Y_{m+1} & =\left(r-Z_{m}\right) h X_{m}+(1-h) Y_{m} \\
Z_{m+1} & =(1-b h) Z_{m}+h X_{m} Y_{m}
\end{aligned}
$$

dengan $m \in N$ dan $h \rightarrow 0$.

Perbandingan perilaku setiap variabel pada model kontinu dan diskret diamati saat $h=0,1 ; 0,01 ; 0,001 ; 0,0001$ dengan parameter $\sigma=10, b=\frac{8}{3}$ dan $r=28$ dan nilai awal $\left(X_{0}, Y_{0}, Z_{0}\right)=(1,1,1)$. Untuk $h$ semakin kecil perbedaan antara kedua model akan semakin sedikit pula. Mulai $h=0.001$ perilaku variabel pada model diskret hampir tidak menunjukkan perbedaan dengan model kontinu. Dari hasil simulasi diskret, efek chaos terjadi pada $t \geq 15$ menit. Saat $h \leq 0.001$, model diskret yang dibentuk dapat mengimplementasikan perilaku variabel kontinu dan gejala kekacauan (chaos) di sekitar titik kesetimbangannya.

Bagi penelitian selanjutnya, disarankan untuk melanjutkan studi diskretisasi model Lorenz ini dengan menggunakan nilai parameter yang berbeda dan bervariasi, agar dapat dilihat keakuratan model diskret yang telah dibangun untuk nilai parameter yang lain. Penelitian selanjutnya juga dapat mengembangkan metode diskretisasi lainnya.

\section{DAFTAR PUSTAKA}

[1] Anonim. TT. Three Dimensional Systems Lecture 6: The Lorenz Equations. www.atm.ox.ac.uk/user/read/chaos/lect6.p df diakses tanggal 5 Desember 2011

[2] Dalmedico, A. D. 2001. History and Epistemology of Models: Meteorology (1946-1963) as a Case Study. Arch. Hist. Exact Sci. 55 (2001) 395-422. SpringerVerlag 2001.

[3] Danforth, C. A. 2001. Why the Weather is Unpredictable, An Experimental and Theoritical Study of The Lorenz Equations. Lewiston: The Faculty of The Department of Mathematics ang The Department of Physics Bates College.

[4] Goldberg, S. 1958. Introduction to Difference Equations. New York: John Wiley \& Son.

[5] Hariyanto, dkk. 1992. Persamaan Diferensial Biasa. Malang: Universitas Terbuka

[6] Liu \& Hussain. TT. Discretization: An Enabling Technique. Arizona: Departement of Computer Science and EngineringArizona State University 
[7] Meyer, W. J. 1985. Concept of Mathematical Modeling. New York: McGraw-Hill Book Company.

[8] O.Knill. TT. The Lorenz System. www.math.harvard.edu/.../118r.../lorentz2. pdf. diakses tanggal 5 Desember 2011.

[9] Ross, S. L. 1984. Differential Equations Third Edition. New York: John Wiley \& Son.

[10] Sazali, M. 2009. Analisis Kestabilan pada Persamaan Lorenz. Skripsi Tidak Diterbitkan. Malang: Jurusan Matematika FMIPA UM.

[11] Tim Penyusun. 2008. Kamus Bahasa Indonesia. Jakarta: Pusat Bahasa
[12] Tirtana, M. A. 2008. Diskretisasi Model Dinamik Kontinu. Skripsi Tidak Diterbitkan. Bandung: Departemen Matematika Fakultas F-MIPA Institut Pertanian Bogor.

[13] Varberg \& Purcell, E. J. 2003. Calculus $8^{\text {th }}$ Edition. Terjemahan I Nyoman Susila. Jakarta: Erlangga

[14] Williams, G. P. 1997. Chaos Theory Tamed. London: Tailor and Francis 